\title{
Investment Problems Facing by Small Businesses: The Case of Construction Material Producing Enterprises in Addis Ababa, Ethiopia
}

\author{
Yemisrach Mulugeta Kebede $^{1} \quad$ Helen Mulugeta Kebede $^{2} \quad$ Eyob Mulugeta Kebede $^{3}$ \\ 1.Ethiopian Construction Design \& Supervision Work Corporation,Addis Ababa, Ethiopia \\ 2.Faculty of Business and Economics, Unity University,Addis Ababa, Ethiopia \\ 3.Arba Minch University, College of natural sciences,P. O. Box 21, Arba Minch, Ethiopia
}

\begin{abstract}
Micro and small enterprises operate within the environment of varies constraints but their contribution to economic development is highly considerable. They are the basis for entrepreneurship and large businesses. This study has attempted to show the problems encountered by small businesses in the construction sector. It particularly looked into investment problems faced by small enterprise engaged in the production of cement materials in selected sub cities in Addis Ababa. The roles of government in the development of investment and the major factors that affect the flourishing of investment are briefly outlined. Some potential problems of investment in business such as access to credit, problems that come from the activities of regulatory bodies, problems in connection with securing land and infrastructure are highlighted. Both primary and secondary data sources were used for this study. For the latter, different sources books and research articles are reviewed through the descriptive type of study. To obtain the necessary information from the primary sources survey method was used. To analyze the data both qualitative and quantitative methods were used. Respondents were asked to give information on the types of ownership of their business and 48(64.86\%) are owned by partnership while $26(35.14 \%)$ by single individuals. In the case of enterprises owned by partnership there are 534 members of which $408(76.46 \%)$ are males and $126(23.60 \%)$ are females. From the whole enterprise only $10(20.83 \%)$ are without female members and the majority $38(79.17 \%)$ comprise both male and female owners. Of which, $40.54 \%$ of them have secondary education and $10.81 \%$ none educated. The findings of the research reveal that high cost of raw materials in the most severe problem cited by the enterprises. The highest percentage of the enterprise indicates that the rising price of raw materials especially cement has put a negative impact on their business. Next to this lack of permanent premise for their operation is brought out as main problem. Many of the enterprise are operating in a premise which is temporary, and a good number of them operate in a rented land and payment for the rent is gone up. Shortage of capital is raised as a third problem of the enterprises. Many of them have expressed that they want to expand their business as market for their products is not a serious problem, but lack of capital has become an obstacle.
\end{abstract}

Keywords: Micro, Small enterprises, Construction material, economy

DOI: $10.7176 /$ RJFA/12-9-01

Publication date:May $31^{\text {st }} 2021$

\section{INTRODUCTION}

The Ethiopian economy mainly depends on the earning of agricultural products. The contribution of these sectors to the GDP was $47.1 \%$ in the year $2005 / 6,46.3 \%$ in the year $2006 / 7$ and $44.6 \%$ in $2007 / 8$. The share of the service sectors such as: whole sales and trade, hotels and restaurants, transport and communication, renting and businesses, education, health and social works was 40.4\%, 41.1\% and 43.4\% in the year 2005/6, 2006/7 and 2007/8 respectively. On the other hand, the share of industrial sectors such as: mining and quarrying, manufacturing, electricity, water and construction was $13.4 \% 13.3 \%$ and $13.1 \%$ in the mentioned years respectively (CSA, 2008:212).

According to CSA, (2008) report the growth rate of GDP in the agricultural sector was $10.9 \%, 9.4 \%$ and $7.5 \%$ in the year $2005 / 6,2006 / 7$ and $2007 / 8$, respectively, whereas the industrial sector shows the growth rate of $10.2 \%, 10.1 \%$ and $10.4 \%$ during the mentioned years respectively. The growth rate of the service sector accounted for $13.3 \%$ in the year 2005/6 and2006/7, while in the year 2007/8 it was $17.1 \%$. It has also reported that the rate of investment as percentage of the GDP was $25 \%$ in the year $2005 / 6,21 \%$ in $2007 / 8$ and $20 \%$ in the year 2008/9. Similarly, the share of GDP from small scale and cottage industries in the year 2006/7 was $2,212,585$ birr and it was 2,754,465 in the year 2007/8.

Micro and small enterprises operate within the environment of varies constraints but their contribution to economic development is highly considerable (Elias, 2005). They are the basis for entrepreneurship and large businesses. Recognizing the role played by small businesses the government of the federal democratic republic of Ethiopia (FDRE) has established the micro and small enterprise agency as of April 3/2008 under the council of minister's regulation No. 33/1998. As stipulated in the article 5 of the regulation, the objectives of the agency 
are to encourage, coordinate and assist institutions which provide support to the development and expansion of micro and small enterprise (Federal Negarit Gazeta No32. April, 3, 1998; 727). This recognition of micro and small business is due to and in line with the free-market economy and the investment policy. The investment policy which is designed to improve the living standards of the Ethiopian people's according to proclamation No. 208/2002 has several provisions for small business development. As it is stated in the proclamation, some of the objectives of the investment policy are to develop the domestic market through the growth of production, productivity and services, to enhance the role of the privet sector in the acceleration of the development of the country economy and create wide employment opportunities for Ethiopians and to faster the transfer of technical knowhow managerial skill and technology required for the progress of the country (Federal Negarit Gazeta No27, 2002: 1770). However, the FDRE government in its industrial development strategy document (1994 E.C; 305-324) shows that lack of capital to start and run the business, lack of land, market access, managerial skills and shortage of skilled laborer, shortage of inputs are recognized as severs problems of MSE. Similarly, a study conducted by Ishergama et al.; (2006) on 105 enterprises from five cities and rural areas of Uganda shows that limited access to production resource, in availability of market access, shortage of capital, access to credit, insufficient provision of infrastructure, inadequate business environment, lack of skilled laborer, high tax payment, high interest rate and corruption were identified as obstacles that hinder the development of small businesses.

Construction sectors play a significant role in a country's development. The construction industry has both direct and indirect impact on a given national economy. It contributes to the national output and simulates the growth of other sector through a complex system of linkages. A lot of construction activities have continued to flourish in the country in the last few years, mainly due to the huge infrastructure projects undergoing by the government including major road, telecom, electric power, condominium houses, real estate etc... and it share in the GDP has been raising and reached about 5-6 percent recently (EEA, 2008; 307). According to CSA, (2008), report, in Addis Ababa a total of 4493 building permits were issued for the construction of residence, industry, schools, commercial buildings, health centers and hotels from the year 2005 to 2007.

The contribution of micro and small enterprises (MSE) is very important to the developments of Ethiopian economy. The great significance and contribution of MSEs are recognized by the Ethiopian government and it is stipulated in the industrial and development strategy (2003) that special attention will be given to their development. As a result, agencies that provide assistance to MSEs is established both at the federal and regional state levels. Despite all these, much progress has not been made as expected. There are a number of problems that retarded the anticipated development of MSEs. The possible problems usually encountered are shortage of capital to start and run the businesses, lack of land or premise, adequate market access, shortage of raw material and rising of input prices. In addition, infrastructure and utilities, high tax rate, shortage of skilled laborer, computation, lack of adequate support from governmental institutions and the general business environments are obstacle to small businesses in the same way (Fasika et al., 1997). The magnitude of the problem also varies from one business to another business. In this manner the problems that faced small enterprises, which produces construction material in Addis Ababa are not studied separately from other small enterprises in detail. Therefore, in this study the problem that faced in this sector in this sector and the extent of the problems will be identified.

\subsection{Materials and methods}

Both primary and secondary data sources were used for this study. For the latter, different sources books and research articles are reviewed through the descriptive type of study. To obtain the necessary information from the primary sources survey method was used. To analyze the data both qualitative and quantitative methods were used.

\subsubsection{Data collection instruments}

The instrument used for the collection of data was questionnaire prepared in Amharic, (Appendix1). The respondents were informed by the researcher about the aim of the study. They were told that the information they provide is only for academic research purposes. Although attempts were made to convince them some did not feel at ease to give information and refused to cooperate.

\subsubsection{Contents of the questionnaire}

The questionnaire was having 25 main items. It was asked information on the nature of ownership, educational level, year of establishment of the enterprises, acquisition of premise and type of production. Moreover, there was a question about sources of capital, amount of capital, credit access, type of raw material used for their product, clients, the number and gender of employees, current condition of the market, production capacity, plan to expand the business, high cost incurred for running the business, relationship with varies government institutions, institutional support, system of tax collection etc...

\subsection{Variables}

As can be understood from the literature review in chapter two and the brief background of the study in this 
chapter many of the researches conducted in Ethiopia and other African countries to the development of MSEs the variables considered in most of the cases were; source of fund for initial capital, credit access, production promise, regulatory constraints, market access, availability of raw materials, infrastructure, production capacity. In addition, skilled labour, training, access of technology, employment opportunities, competition, corruption, taxation high collateral and opportunities for growth and expansion are considered. Hence, taking into consideration the scope and limitations or this study the main variables that are believed to facilitate the examination of the major problems faced by the small business investors are selected namely, source of capital, premise, market access, infrastructure (utilities such as water, power telephone) skilled labour, availability of raw materials, cost of raw materials, maintenance, competitions, tax, institutional support, licensing interest rate, transport and wage.

\subsection{Study Area and Sample Size}

The research focuses on small enterprises engaged in the production of cement materials (hollow blocks, precast beams, tubes and etc.) found in Addis Ababa. Addis Ababa with a total population of 2,738,248 (CSA 2008:23) is divided in ten sub-cites (Kifle Ketemas) namely, Addis Ketema, Akaki, Arada, Bole, Gulele, Kirkos, Kolfe Keraniyo, Lideta, Nifasilk Lafto and Yeka.

From the list available in Addis Ababa Micro and Small Enterprises Development Agency (AAMSEDA) it was possible to identify 80 small enterprises found in the selected six sub cities. The distribution is 16 in Arada, 3 in Bole, 5 in Kirkos, 10 in Gulele, 21 in Nifasilk Lafto and 25 in Yeka sub cities. The enterprises were selected using the criteria set by the Ministry of Trade and Industry which is a capital of 20,000-500,000 Birr for small enterprises.

On the other hand, through a door-to-door visit of sites by the researcher and a friend assistant it was possible to find 12 more small enterprises. So, the total population of small enterprises reached 92 . Since the population was not large there was no need to select samples and all were included in the study. Of the total population (92) 74 owners of enterprises were willing to fill out the questionnaire the remaining 18 refused. Hence, the study is based on 74 enterprises.

\section{Data Presentation and Analysis}

\subsection{Nature of ownership}

The respondents were asked to give information on the types of ownership of their business. According to the response obtained 48(64.86 per cent) are owned by partnership while 26(35.14 per cent) by single individuals. In the case of enterprises owned by partnership there are 534 members of which 408(76.46 per cent) are males and $126(23.60$ per cent) are females. From the whole enterprise only 10 (20.83 per cent) are without female members and the majority 38(79.17 per cent) comprise both male and female owners. When we look at the number of individual female owner enterprises only two females were found out of the 26 . The highest number of members in an enterprise was 21, while the lowest was five however, 27 (56.26 per cent) of the enterprises were have 5-10 members.

\subsection{Level of Education}

The owners of the small enterprise were asked to indicate their level of education. According to their response 40.54 percent have secondary education, 27.02 percent of them above secondary, 21.62 percent have primary education and 10.81 percent none educated. The level of education has training implications and from this data it can be anticipated that the majority of the owners are trainable.

\subsection{Ownership of Premises}

Investors need appropriate premise in which they operate. The premise can be owned privately or secured though rent. Respondents were asked to provide information on the status of the land in which they are operating. It was found that most of them 58,11 percent operate in a premise given by Kebeles and sub cities on temporary basis. Very few 4.05 percent operate in privately owned permanent premises, while a good number of them 37.84 operate in place secured though rent. 


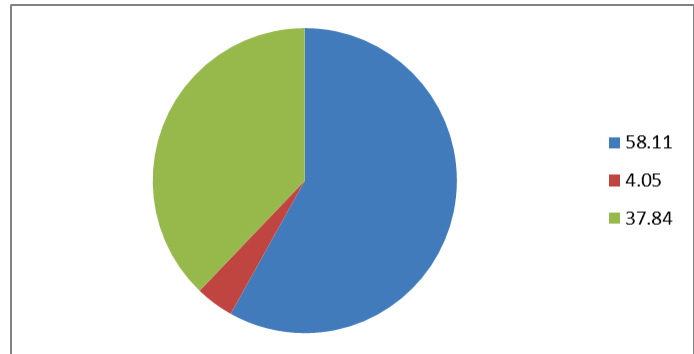

Fig. 1 percentage of ownership of premise

\subsection{Types of products}

Generally, the enterprises engaged in the production of construction produce hollow blocks of different sizes, precast beams, floor tiles, and tubes of different sizes, but all of them do not produce all the types mentioned. Some are engaged in the production of blocks while others produce two or three of the types. 48 of the enterprises produce hollow blocks, 15 produce blocks and precast beams, 8 blocks, tubes and floor tiles and precast beams.

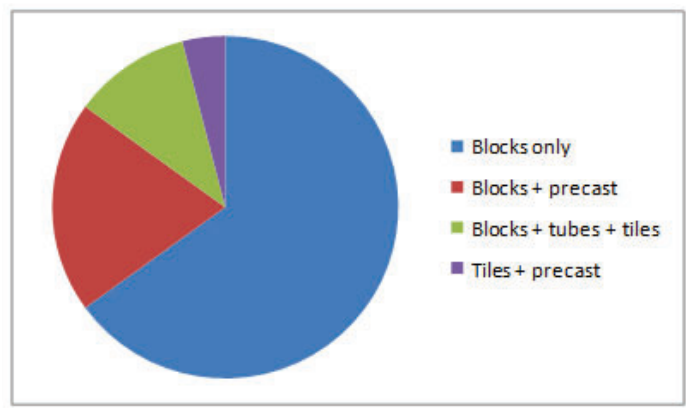

Figure 2 show percentages of enterprises in terms of the types of product

\section{5 source of fund for starting the business}

According to the literature on micro and small enterprises financing, there are various possible sources for initial capital of investment. Starting money can be obtained from own savings, families, friends, individual money lenders, credit association, banks credit and saving institutions, micro-financial institution (MFIs) and especially in the case of Ethiopia" Iqub". These financial sources have their owe requirements and criteria for lending money. The owners of the seventy-four small enterprises in this study were asked to indicate the source of their initial capital. The highest number of the enterprises (41.89 per cent) responded that they obtained the startup money from microfinance institutions. The following Table.1 shows the details. From the above table we can see that bank loan is the lowest case and when the respondents were asked the reason why they did not opt for bank loans, many of them said that due to the collateral and other requirements they did not dare to request banks.

Table 1 Source of startup capital

\begin{tabular}{|l|l|l|}
\hline Source & \multicolumn{1}{|c|}{ Number of Enterprise } & $\%$ \\
\hline Own saving & 25 & 33.78 \\
\hline Family & 4 & 5.41 \\
\hline Friends & 0 & 0 \\
\hline Bank & 4 & 5.41 \\
\hline Micro-finance inst. & 31 & 41.89 \\
\hline Individual lenders & 2 & 2.70 \\
\hline Iqub & 0 & 0 \\
\hline MFI and own saving & 8 & 10.81 \\
\hline
\end{tabular}

\section{6 production capacity and market}

The small enterprise was asked to indicate the current situation of their production. A good majority of them (62.16 percent) said that due to the shortage and rising price of raw materials particularly cement, they could not produce with their full capacity. Respondents were asked about the situation of the current market of their products. 
Table 2: Production capacity

\begin{tabular}{|l|l|l|}
\hline Capacity & No. of Enterprise & $\%$ \\
\hline Full & 28 & 37.84 \\
\hline Half & 33 & 44.59 \\
\hline Quarter & 8 & 10.81 \\
\hline One third & 5 & 6.67 \\
\hline Total & 74 & 100.00 \\
\hline
\end{tabular}

Although many of them are not producing with their full capacity as indicated above, the demand for their products is not bad, as indicated in the (table 3) 44,59 percent of the respondents said that market of their products has increased than before.

Table 3: Market Situation

\begin{tabular}{|l|l|l|}
\hline Situation & No. of Enterprise & $\%$ \\
\hline Decreased & 28 & 37.84 \\
\hline Increased & 33 & 44.59 \\
\hline Same & 13 & 17.57 \\
\hline Total & 74 & 100.00 \\
\hline
\end{tabular}

In connection with the demand and market of their products the small enterprise was asked to indicate in rank order their clients. The following were their responses.

Table 4 Ranking of clients

\begin{tabular}{|c|c|c|c|c|c|c|}
\hline \multirow{3}{*}{ Client } & \multicolumn{6}{|c|}{ Rank } \\
\hline & \multicolumn{2}{|l|}{$1^{\mathrm{st}}$} & \multicolumn{2}{|l|}{$2^{\text {nd }}$} & \multicolumn{2}{|l|}{$3^{\text {rd }}$} \\
\hline & No. & $\%$ & No. & $\%$ & No. & $\%$ \\
\hline Government Organization & 42 & 56.5 & 0 & 0 & 7 & 9.45 \\
\hline Private organizations & 6 & 8.1 & 16 & 21.62 & 6 & 8.10 \\
\hline Individuals & 26 & 35.13 & 13 & 17.56 & 5 & 6.75 \\
\hline
\end{tabular}

From this we can conclude that first the clients taking products of the small enterprise are government organizations as they are out first 42 percent and second 56.5 percent.

\section{7 proximity of raw materials source to production site}

One of the possible factors that affect the rise of prices in the cost incurred in the transportation of raw material from their origin to the production sites. As transport cost in partly dependent on the proximity of sites respondents were asked to indicate in a scale of four (near, far, very near and very far) the proximity of the place from where they purchase much of the raw materials to the manufacturing site. Of the 74 respondent's 54.05 percent said that the places from where they get the raw material were very far and only 1.35 percent said that the places were very near to the production site, and 2.70 percent said near and 41.90 percent said far.

\subsection{Employment Conditions}

The small enterprise in the study have employed a total of 1231 persons of which 901 (73.19percent) are males and 330 (26.81 percent) are females. When we look at the term of employment, we do not find much difference between the number of temporary and permanent employees. The number of persons employed on temporary basis is 621 (50,45 percent) and the number of permanent employees was 610 (49.55 percent). We can also see the disparity between male and female employees. The number of employees varies from enterprise to enterprise. The maximum number of employees in an enterprise is 45 while the minimum is five. The highest percentage (27.03 percent) of employees falls within the range of $31-35$ and $41-45$ employees $(2.70$ percent each)

\subsection{Training}

Training is an important component of small business development. In the literature it is emphasized that in order to enhance entrepreneurship in the area of small businesses specialized training should be offered to those who come to the business without prior formal training. Training programs tailored for the new entrepreneurs can build the capabilities of small enterprise. (Steel, Osei et al. 1993). It is also emphasized in the industrial development strategy of the government of Ethiopia (1994E.C) that training of young entrepreneurs is very vital to the development of small businesses.

In connection with training respondents were asked to indicate the type of training they have taken before or after the starting of their businesses. 45.95 percent of the enterprise responded that they have various trainings while 39.19 percent indicated that they have not taken training of any sort. 


\subsection{Bureaucratic Problems}

One of the possible problems that small enterprise face comes from the bureaucracy in different institutions. Respondents were asked to rate the bureaucratic problems they encountered while seeking support and request of facilitation to the running of their businesses. 67 enterprises answered the question and seven did not respond to this particularly question. of those who gave their response the highest 46.26 percent rated the problems as moderate, and the lowest, 4.48 percent rated the problems encountered high. With regards the types of problems faced in various offices the respondents mentioned delay of replies to their requests, missing appointment, lake of assigning appropriate persons who can give the necessary information and guidance.

\subsection{Tax collection System}

Taxation is an important factor affecting the operation of MSEs one aspect of it is the way in which the concerned authorities collect the tax from the owners of the enterprises. Respondents were asked to express their views with regard the process of tax collection. Of the seventy-four enterprises 64 gave their views while the remaining 8 did not answer this particular question. Those who answered 93.75 percent indicated that the collection system was simple and clear while 6.25 said it has got problems.

\subsection{Institutional support}

The respondents were asked to name institutions that provided them with support of any kind in connection with their business operation. Many of them mentioned that they got support from Kebele and sub city offices, microfinance institution, Addis Ababa micro and small enterprise development Agency.

Respondents were asked to list he support they got from the different offices. Buying products, creating market linkages, providing temporary premise for operation, supply of raw materials, moral support and advice were the main support that they obtained from kebele and sub city offices. They also mentioned that they got support from micro-finance institutions and Addis Ababa micro and small enterprises development agency in terms of loan, training, market linkage and moral support.

\subsection{Relationship with offices}

The respondents were asked to rate in a scale of four (simple, moderate, difficult, and very difficult) the relations they had with various offices that they contacted in connection with their business operations. The particular offices selected were Addis Ababa Trade and Industry (AATI), Micro and Small Enterprises Development Agency (AAMSEDA), Kebeles and sub city in which the business premises are found, Addis Ababa Water and Sewerage Authority (AAWSA), Ethiopia Electric power corporation (ETC). These offices were selected because it is believed that they have somehow contributions to the operations of the businesses. This item was answered by 70 of the enterprises and four did not indicate their ratings.

\subsection{Plans for Growth and Expansion}

Respondents were asked whether or not they have a plan to expand their business of the total respondents 87.83 said they have a plan to expand their business while the remaining 12.17 percent said due to the problems particularly shortage and rising prices of raw materials, they do not have plan or expansion.

\subsection{Ranking of problems}

Investors encounter different problems. According to the literature, the possible problems usually encountered are shortage of capital to start and run the business, lack of land of premise, adequate market access, and shortage of raw materials and rising prices of inputs. Moreover, they can face problems of infrastructure and utilities such as shortage of power, water and inadequate telecommunication services. High tax rate, shortage of skilled labor, competition, lack of adequate support from government institutions and the general business environment could create obstacles to small business investment.

The enterprises were asked to indicate in rank order (1-12) the problems they have faced according to the severity of the problems. The result indicates that cost of raw materials, lack of premise and shortage of capital are ranked as first, second and third respectively by those who answered the question. 


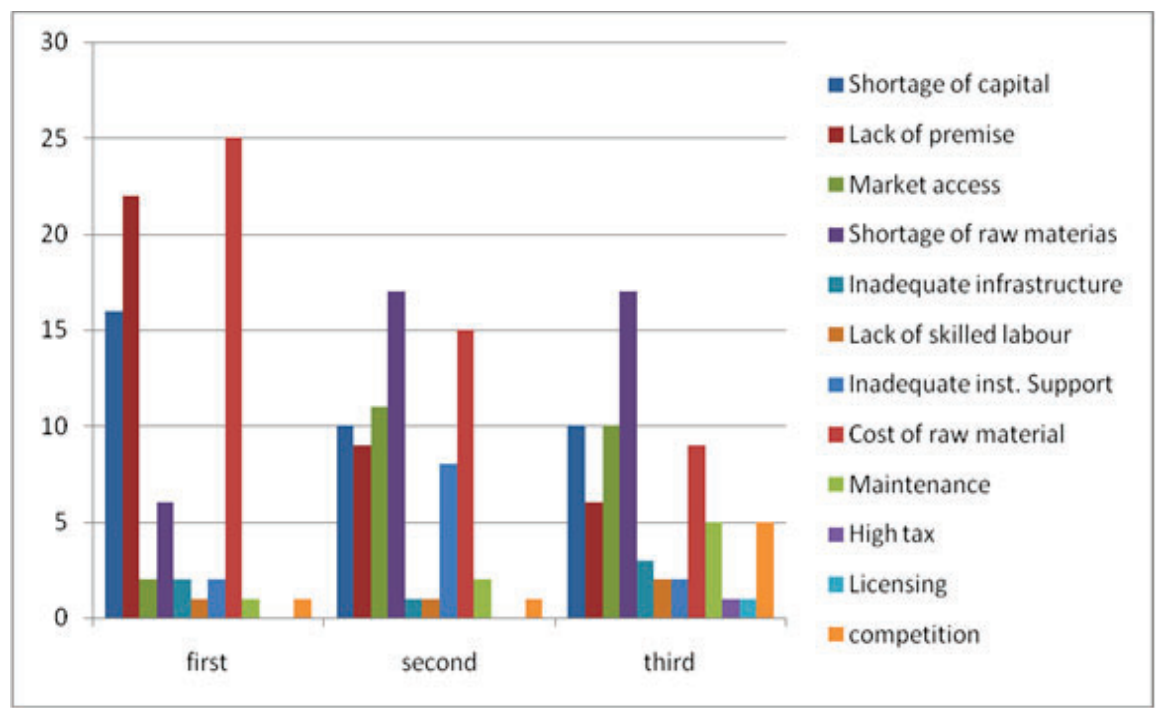

\subsection{Conclusion}

The study has attempted to show the problems encountered by small businesses in the construction sector. It particularly looked into investment problems faced by small enterprise engaged in the production of cement materials in selected sub cities in Addis Ababa. As a background to the study some aspects of the Ethiopian economy are presented so as to briefly introduce the general situation. The roles of government in the development of investment and the major factors that affect the flourishing of investment are briefly outlined. Some potential problems of investment in business such as access to credit, problems that come from the activities of regulatory bodies, problems in connection with securing land and infrastructure are highlighted. The importance of construction industry is another point raised in the background this is raised because the role of the small enterprise in supporting the construction sector in recognized.

The importance of small enterprise is reflected in various studies as indicated in the literature review. They have a great role to play particularly in poor countries. As is observed in the literature review, they are sources of employment especially for poor families and financially disadvantaged sector or societies, they are also the basis for the development of large and medium enterprise. Their contribution to poverty alleviation is also stressed. Their role in the mobilization of saving for productive activities is also recognized.

The findings of the research reveal that high cost of raw materials in the most severe problem cited by the enterprises. The highest percentage of the enterprise indicates that the rising price of raw materials especially cement has put a negative impact on their business. Next to this lack of permanent premise for their operation is brought out as main problem. Many of the enterprise are operating in a premise which is temporary, and a good number of them operate in a rented land and payment for the rent is gone up. Shortage of capital is raised as a third problem of the enterprises. Many of them have expressed that they want to expand their business as market for their products is not a serious problem, but lack of capital has become an obstacle.

\section{References}

Andualem Tegegne (1997) Small-Scale Enterprise and Entrepreneurship Development in Ethiopia concepts, definitions and Major Issues. In; Wolday Amha, Chipande G. M. R and Andualem Tegegne (eds). (1997). Small-Scale enterprise development in Ethiopia. Proceedings of the sixth annual conference of Ethiopia Economy. Addis Ababa.

Barwa, S.D, Structural Adjustment Programmes and the Urban Informal Sector in Ghana. http: // www- ilomirror. Cornell. Edu /public/ engilsh / employment / start/ publ / iddp3. htm (retrieved on march 25, 2009).

Bjerke, Bjorn and Claes M. Hultman (2002) Enterprise Marketing: The Growth of Small Frims in the New Economic Era: Edward Elgar Publishing Limited. Chltenham.

Ethiopia Economic Association (EEA) (2008) Report on the Ethiopian Economy vol. VI 2006/07. The current state of the construction industry.

Elias Berhanu (2005) Role of Micro and Small Enterprises in local economic development, the case of Awassa. In: Tegegne Gebre Egziabher and Hemsing, A. H. J (eds). (2005) Local Development in Africa: Enterprises communities and Local Gvernment. Shaker publishing. Maastricht.

Fasika Damte and Daniel Ayalew (1997) Financing Micro and Small-Scale Enterprises in Urban Ethiopia. IN: Wolday Amha, Chipande G. M. R and Andualem Tegegne (eds). (1997) Small-Scale enterprise development in Ethiopia. Proceeding of the sixth annual conference on Ethiopian Economy. 
Federal Democratic Republic of Ethiopia Centeral Statistical Agency (CSA) statistical Abstract. 2008

Federal Negarit Gazeta NO. 32 3rd April 1998.

Federal Negarit Gazeta NO. 27 2ndJuly 2002

Gebrehiwot Ageba and Wolday Amha. (2006) Micro and Small Enterprise (MSE) Development in Ethiopia: Strategy Regulatory Changes and Remaining Constraints. Ethiopian Journal of Economics Vol. X No. 2, 2001 (published in 2006). Addis Ababa.

Helmsing, A. H. J. Th. Kolstee (1993) (eds). Small Enterprises and Changing policies. Structural adjustment, financial policy and assistance programmes in Africa. Intermediate Publications. London. (1993) small enterprise promotion in a changing policy environment in Africa: raising issues and attempting answer in:

Helmsing, A. H. J and Th. Kolstee (eds) (1993) Small Enterprises and Changing policies: Structural adjustment, financial policy and assistance programmes in Africa: Intermediate Publication London.

Ishengoma, Esther K. and Robert Kappel Micro and small Manufacturing enterprises in Uganda. http:// 74.125.77.132/ search?q=cacheLU5Nrx GS6QJ: www.giga-hamburg.de/dl/down/oa... (retrieved on March 24, 2009)

Tegegne Gebre Egziabher and Mulat Demeke (2005) Micro-enterprises performance in Small towns, Amhara Region: implications for local economic development. In: Tegegne Gbere Egziabher and Hem sing, A.H.J (eds) Local Development in Africa: Enterprises communities and Local Government. Shaker publishing. Maastricht

Wolday Amha. (2002) The Role of finance and business Development Service (BDS) in Micro and Small Enterprise (MSE) Development in Ethiopia. Association of Ethiopian Microfinance Institution. Occasional Paper No. 5. Addis Ababa 